\title{
INDIVIDUAL ITEMS OF SPECIAL INTEREST IN THE FORBES COLLECTION
}

\author{
by
}

David Sinclair

Forbes' library is a fascinating collection, for, in a way, we can still visit his study as he left it, though in the intervening centuries its contents have been visited by fire and flood. My interest here has been to cull the sixteenth-century material and to present some of the interesting items; the choice was personal, with an eye for those items which might complement existing collections on campus. The selection following does not represent any one trend in the collection. Though a student of seventeenth-century bibliography could well make a study of collecting habits from the Forbes stock, the sixteenth-century material is simply not extensive enough for meaningful trends to be established. The core of the material is Biblical commentaries. A seventeenth-century trend in Forbes' library, the emphasis on church and state, is reflected in the Elizabethan controversial literature, some of which appears below.

Forbes inscribed his volumes with Fugit hora, tempora, labora..., but not, alas for the curious librarian, with the prices paid, or the provenance and date of acquisition. A previous owner of one of the titles I treat has done so (unless I read his shelf-mark for eighteenpence). But we can assume that Forbes was not a bibliographer or book-hunter: there is no reason to imagine that his sixteenthcentury books were actively sought with the purpose of forming an integrated subject collection, or for their fine printing or bindings. Forbes was after all a preacher, and the printed word, especially Biblical commentaries, would be the tools of his trade. Both the time and his tasks were fleeting, as he so carefully noted, and he had no call to spend loving care upon the niceties of bibliography as the custodians and users of his library now must do.

To this end, a selection from among Forbes? books. The annotated bibliography following has been done with the hope that it may be of reference value. Thus the transcription of titles and imprints is rather more full than is seen in usual checklists. Language and orthography has been preserved, but typography has in most instances been silently corrected. No collation was felt necessary。 Authors? names, where this has been possible, have been made to accord with the standard entries in the Library of Congress catalogues.

I. Acc 24670

NICOLAS de Lyre, d. 1349?

Quarta pars dri Nicolai de Lira cum suis additioibus. deg replicis tractans super toto corpore biblie.

Colophon: Exactũ est Argẽtine insigne ho ac inusitat op biblie vnacu postillis venerãdi viri ordinis minoll frîs Nicolai de lyra。 cưg additiőibs p venerabilẽ ễm Paulũ burgêsem edit ac replicis mgrึi Matthie dorinck eiusdem ordinis .... impressum habes iucundissimo. exempletum denigh Anno in-

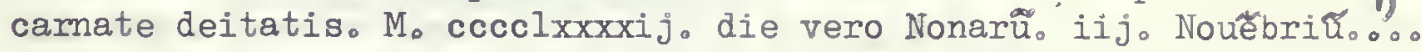

Vol。 4 of BIBLE。 Latin, 1492 .

Printer: Johann Grüninger. (Johann Reinhard of Grüningen)。 RBD copy damaged: Sigo a replaced by photo facsimile; waterstaining。 BMC I.108; Hain *3169; Goff B617。 
Nicolas de Lyra was a French theologian whose dates are estimated in one source to be ca.1270-1340. Many editions of his commentaries on the Bible were done in the incunabula period; other editions have the work of Paulus Burgensis and Mattias Doringk as well.

Johann Grüninger the printer vas sometime at Basle, and at Strasbourg from 1482. He was a correspondent of Amerbach, with whom he had worked. He produced editions of the classics, sermons in Latin and German, medical texts, dictionaries, even novels: over 250 titles, by one count. He printed for others as well, including Koberger. Kristeller finds him the principal representative of the Alsatian school of illustration, and book illustration seems to have been his chief concerm in printing from the time of his establishment in Strasbourg until his death ca.1531.

This is Forbes' only incunabulum, and not a particularly exciting item. The rains of Gloucester have done considerable damage to the volume.

2. Acc 19943

ERASMUS, Desiderius, d. 1536 。

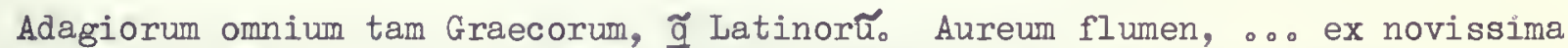
D. Erasmi Rot。 aeditione brevi cơmentariolo, secundum ordinẽ alphabeti, per Theodoricum Cortehoevium selectum ...

An。 $M_{0} D, X X X$

Colophon: Adagiorum omnium tam Graecorum quam Latinorum finis. Antverpiae in officina Martini Caesaris, impendio ac aere honesti viri Godfridi Dumaei bibliopolae. Anno ab orbe redempto M.D。XXX, XIIII Calendas Martii。 Cum gratia et primilegio imperiali。

Bibliotheca Erasmiana (1897) IV, 267.

This was the fourth condensed Adagia; the version contains about 3,467 adages with commentary. It was undertaken as a student edition. The adapter, Theodoricus Cortehoevius, takes his name from Kortenhoef, Holland, his birthplace. Around 1530 it is likely that he was living at Antwerp; his lefter to Erasmus at the beginning of this volume is dated there. Only two of his works are known: this Adagia, and Bellum Sophiae ac Philantiae, Veritatis ac Falsitatis (Antwerp, GoDumaeus, 1530).

The printer, Martinus de Keyser (Caesaris) printed some sixty titles in Antwerp between 1525 and 1536-7. His widow printed twenty titles betiveen 1536 and 1539. Of Erasmus' texts, de Keyser printed the following:

Enchiridion du chevalier chrestien (1529)

Enchiridion militis christiani (1531)

Declarationes ad censuras Lutetiae vulgatas (1532)

De civilitate morum puerilium (1532)

De praeparatione ad mortem (1534)

His widow printed Erasmus' Catalogi duo operum ab ipso conscripti et digesti in 1537. The publisher Govaert van der Hagen (Dumaeus) as a printer had produced a Dutch Eusebius in 1534 。

The binding is blind-stamped calf, worm, the central feature of which is the laureated head of a bearded man. The decoration is similar to that on the work of another by the name of Erasmus in Forbes' collection, Erasmus Sarcerius 
(see Acc 21959)。 Both bindings have been rebacked, but the covers appear to be contemporary with the publications. Profile heads as panel motifs appeared in Fingland ca.1528-30. They follow by one hundred years a turning in Florentine portraiture to the finest examples on classical Roman coins and medals. The similarity of the Desiderius Erasmus binding to that of the Erasmus Sarcerius makes one wonder if the same binder worked at them both. This speculation aside, we can tell earlier ormers. The Adagia was signed twice on the title page by one William Levis: Liber guillielmi Leuisii。 One signing continues: $153318^{\mathrm{d}}$; the latter figure I interpret as the price. One Watson has signed the book at the foot of the Epigramma ad lectorem.

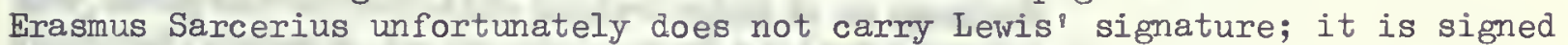
by James Allen on the title page, and by W.Masters (and again, Maisters) at the end. There is some early marginal commentary。

3. Acc 24761

PELLICANUS, Conrad, 1478-1556。

\section{[Commentaria Bibliorum]}

[Tiguri, Apud Christophorum Froschoverum;, mense Augusto Anno M॰D。XXXII。] RBD copy lacks sig.A., B (10 leaves)。

Title from p.1: "Commentarium breve, simplex et catholicum in sacrosanctos viginti quatuor veteris instrumenti Canonicos libros ... per Chuonradum Pellicanum Rubeaquensem o...

$4 \mathrm{v}$. in 2 , of 8 。

Konrad Kürsner:(Pellikan) was called with Oecolampadius as professor of theology to Basel in 1523. Three years later he went to Zurich where he was professor of Greek and Hebrew, and eventually librarian. He was closely associated with Zwingli, and had had dealings with Luther, as well as being a friend of Erasmus. Pellikan worked for Froben, contributing indexes to the works of Erasmus, Oecolampadius and Beatus Rhenanus. He also worked for Adam Petri whom he moved to print many of Luther's works. His commentaries came out of Froben's shop in separate lots, over the period between 1532 and 1582. The edition to which the present copy apparently belongs is the $1532-46$ edition in eight volumes。

Christoph Froschauer (ca.1490-1564) worked in Zưrich for Hans Rliegger and married his widow. He was the printer of Zivingli and Bullinger, and became the "offiziőzer Drucker des Rates"。 Latin, German and English texts of the Bible were done in his shop. His nephew and namesake carried on the business until 1585 .

(See also notes to Acc 22287).

Acc 21959

Sarcerius, Erasmus, 1501?-1559。

Methodus scripturae divinae, ad nuda didactici generis praecepta o.o

[Marpurgi, Apud Chr。Egenolphum, 1544]

$2 \mathrm{v}$ 。

Dedicated to Henryy VIII. 


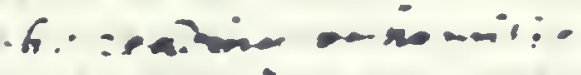

CCCXCIX.

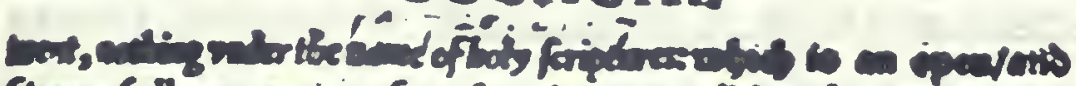

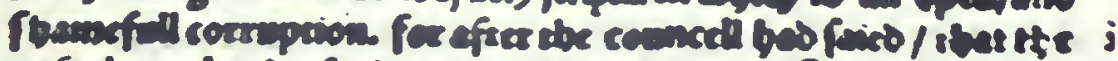

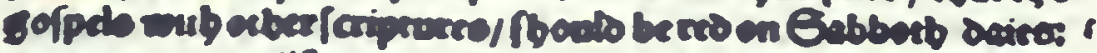

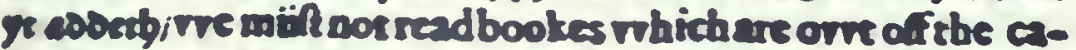

5. non, but the canonicall bookes of the old and now wefament

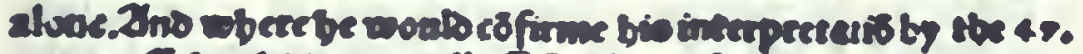

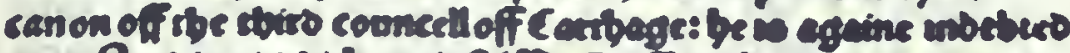

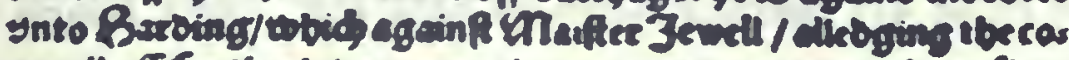

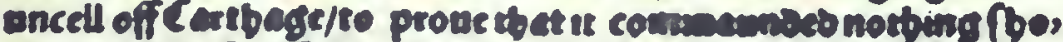

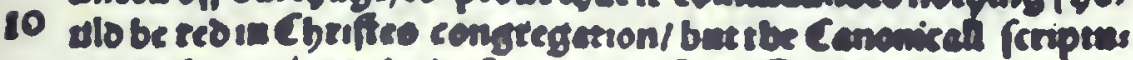

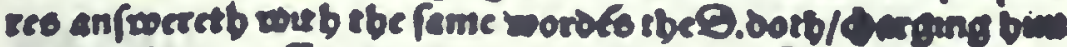

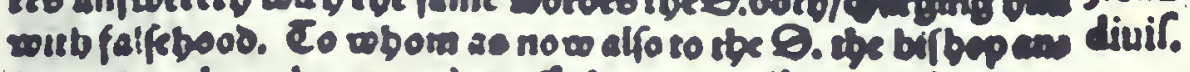
fweterb/ that the ancaning off the councell was, that nothing els floulde be rad:wobid beproustb by the cauncell of 15. Bippoj an abrtogenaent off thet of Certoage: wobereitiorbus meritren. The feriptures canonicall which are to bered in the chap. 3 th church, and befide ruhich nuthing may be rediand fo gor $\$ b$ for wars al!ergingotber icflimonice/affirming paxtly ther notbing

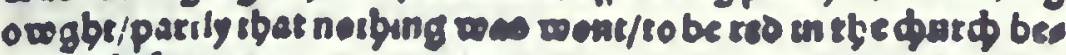
fioc boly fertprare.

Bie anjwere to she councell of Colen/ to roo dibith. Ebe councelo wordes in abe /uxt Canon ace tbefe/vrhere in times paft ye rras ordeimed off the most holy fatbers, that the holy feri-

S5 peures alone Thoulde be red in the church: rre knovre nor by vwhat carelefnes, other not to be compated vith them, are cume into their place. Doberby appeckerb / sbat it condenneth not

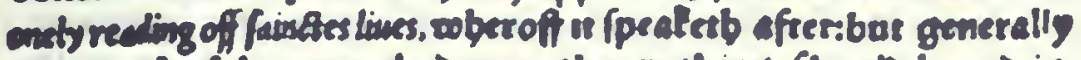

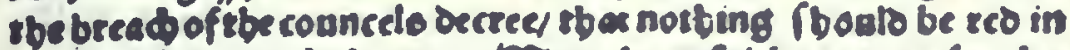
the durd / but boly feripture. Dobere be nufreb bow we en fay, that

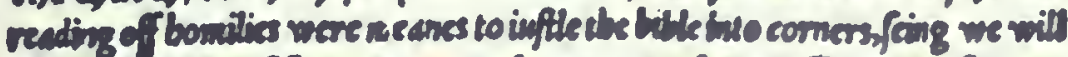

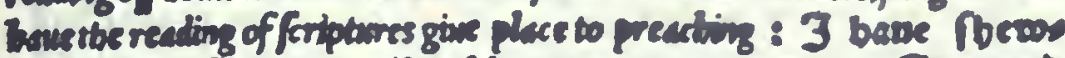
co bow groffe/and into!lerableignorence it io/ wbere 3 proses

sbe excellency of presding before fimple secoing off farptares/

suref pecially beforebomilica. Ebe obsection whe 3 mebe off

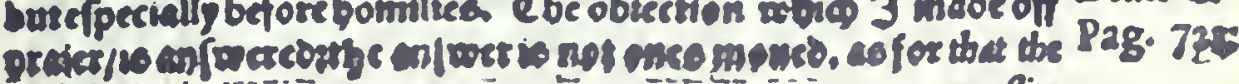
mexplity
Inthe def A po. lo.s. part. 3.cha 10.

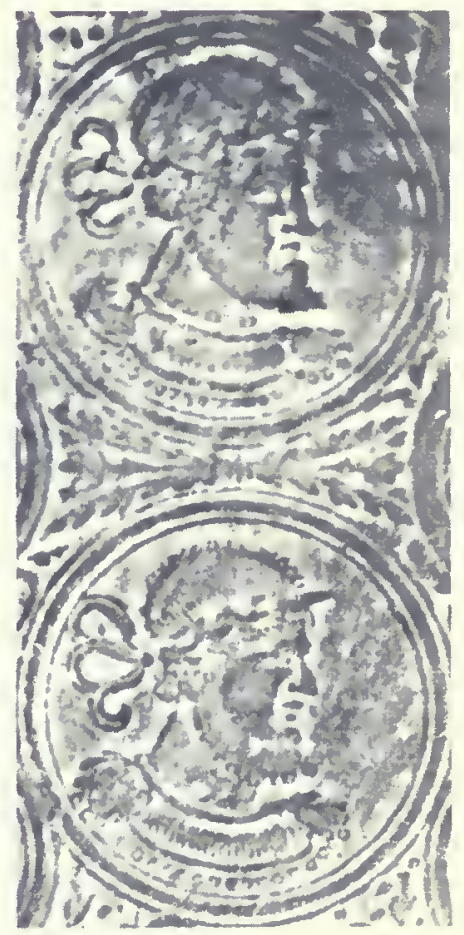

Erasmus, Adagia (19943). Detail from a rubbing of the front cover, showing the central motifs.

Cartwright, The second replie (22287). Typography and spellings indicate foreign printing. This

passage mentions the controversy between Harding and Jewel (see 24561). 
Sarcerius (Sorck) was a German Lutheran, educated at Leipzig, Wittenberg, Vienna and Rostock. After 1528 he was a teacher at Liabeck. In 1551 he was one of the theologians to whom the Saxon Confession was submitted for approval and subscription, and in the following year was a member of the unsuccessful delegation to the Council of Trent, which got no further than Nuremberg. Sarcerius wrote many commentaries on the books of the Bible. His Loci aliquot communes et theologici was translated by Richard Taverner (the translator of the other Erasmus) in 1538, the year of its publication. It went through several editions as cómon places of scripture ordrely set forth.

Egenolff, Christian, 1502-1555. The printer Egenolphus studied at Mainz. He printed at Strasbourg from 1528-1530, and at Frankfurt a/M from 1530-1538. He was a prodigious printer in the sciences, medicine, history and the classics. In Marburg he set up a branch in 1538, and later (1541) took over the Cervicorus equipment. He was university printer there until he turned his business over to Andreas Kolbe in 1543. He had a branch at Hohensolms which flourished around 1548. His shop operated through his heirs until 1605.

Binding similar to Forbes Acc 19943: see illustration, p。17。

5. Acc 21811

BUTZER, Martin, 1491-1551。

[De regno Christi Jesu ... libri II. Ad Eduardum VI。 Angliae regem, annis abhinc sex scripti ... D. Martino Bucero autore ....

Basileae, Per Joannem Oporinum [1557]

Colophon: Basileae, Ex officina Joannis Oporini, Anno Salutis humanae M.D.LVII。 Mense Septembri.

Praefatio signed: Argentorati, Calendis Septemb。 Anno M。D。LVII。S。M。T。 deditissimi, haeredes defuncti in Christo Martini Buceri。

RBD copy damaged, with some loss of text。

Butzer (or Bucer) was born in Schlettstadt (Sélestat) Alsace. A principal reformer at Strasbourg, he attempted to mediate the quarrel between Zivingli and Luther. He played a significant role in the various conferences prior to the Schmalkaldic War between Catholics and Protestants. In 1548 he fled to England, where he was made Regius Professor Divinity at Cambridge. There he died three years later.

The De regno Christi is Butzer's manual for the establishment of a lasting Reformation in England. Drafted sixteen months after he arrived in England, it is in two parts. The first consists of an analysis of the idea of the kingdom of Christ and of the chief functions of the Church. The second, more practical, part has Butzer's suggestions with regard to the establishment of this kingdom in England, and of the legislation which must go along with it. After circulating in manscript since Butzer's death, and being the subject of considerable negotiation with printers, the work was sent by Butzer's secretary Conrad Hubert to Oporinus in June 1557. In scarcely two months the printed product was ready for the fair at Frankfort. 
Johann Oporinus, 1507-1568 (whose family name was Herbst), worked for Froben correcting texts in 1526. He was a student of medicine, and for a time famulus to Paracelsus. Browning's Paracelsus says to Festus of him: "Oporinus/ Has pilfered half my secrets by this time ..." (IV, 619). Many accusations against Paracelsus -- drunkenness, blasphemy, etc. -- seem to have proceeded from Oporinus, a fact that he regretted at a later date. As an energetic scholar-printer he brought out more than 700 items, including the illustrated Anatomy of Vesalius.

6. Acc 20565

PFLACHER, Moses.

Analysis typica omnium cưm veteris, tum novi Testamenti librorum historicorum: ad intelligendam rerum seriem, et memoriam iuvandam accomodata .... Editio quarta.

Basileae, per Conradum Waldkirch, 1606.

Pflacher was the pastor at the church of Kempten (pastor ecclesiae Campidonensis), and the author of at least two other books: Christliche Predig von dem unkraut des Zvinglische unnd Calvinischen Irthumbs ... (Regenspurg, 1584), and Weintherre, oder Bericht auss Gottes Wort ... (Tiibingen, 1589)。 The preface of the Analysis is signed 1587; the same year saw an "editio secunda" in London, printed by Bollifant. The Bibliotheque nationale records an "editio quinta" of 1587 by Waldkirch. If this latter is not an error -- rare in the BN -we can assume that Pflacher's book was well-received.

The Analysis is an elaborate series of charts of Bible passages, elaborated and dichotimized under the influence of Ramus"."method." "Method" methodus) was Ramu'' term for orderly pedagogical presentation of any subject by reputedly scientific descent from "general principles" to "specials" by means of definition and bipartite division. This scheme made its first appearance in Ramus? Dialecticae institutiones, 1543 .

Konrad von Waldkirch, 1549-1616?, was printing in Basel from 1584。 He established the first press in Schaffhausen in 1591-2, an accomplishment where Henri Estienne had failed in 1587. He printed a high percentage of German authors, philosophy, \& theology. His products include texts in Greek and Hebrew。

7. Acc 24561

HARDING, Thomas, 1516-1572。

A confutation of a booke intituled an Apologie of the Church of England.

Imprinted at Antwerpe, by Ihon Laet, with Privilege. 1565.

Royal arms on verso of title page.

Dedicated to Queen Elizabeth.

STC 12762 .

Harding recelved his MA from Oxford in 1542. He was chaplain to Henry Grey, marquis of Dorchester and had a hand in the religious education of his daughter Lady Jane Grey. She, when in prison and having heard of his conversion to Romanism wrote calling him the "deformed imp of the devil" and "the unshameful paramour of Antichrist". When deprived of office by Elizabeth, he went to 
Louvain, where he wrote his side of the long and wordy controversy with Jewel。

This text is dedicated to the queen, and is interesting as compared to Bilson's work (Acc 20588). Harding writes to Elizabeth:

Your good inclination towards the auncient and catholike religion which the authours of that Apologie with an odious terme do call papistrie, encourageth me not a litle unto your Majestie to offer this gift and service.

He praises Elizabeth's use of the crucifix ("the reverent use of the crosse in your private chappell...."), and her "advised staye from hasty and sharp persecution, [and] quiet bearing of your sword within the scabbard." Harding concludes the dedication with a polite warning:

God ... hath hitherto stayed your Majestie in this moderation which we see, and holden backe your princely handes from th'use of your sworde against those of your subjectes who stand in profession of the auncient and thuniversall faith of all Christendom (from which no terrour of sworde can remove them) ....

8. Acc 22287

CARTWRIGHT, Thomas, 1535-1603.

A replye to an answere made of $M_{\text {o }}$ Doctor Whitegifte againste the admonition of the Parliament, by T. C.

[Wandsworth, J.S., 1573-4]

Title page in facsimile. STC 4711 or 4712 。

bound with his

9. The second replie of Thomas Cartiright: agaynst Maister Doctor Whitgiftes second answer touching the Churche discipline.

Imprinted M.D。LXXV。

STC 4714 .

bound with his

10. The rest of the second replie of Thomas Cartwrihgt [sic]: agaynst Master Doctor Whitgifts second answer, touching the Church discipline。

Imprinted M。D。LXXVII。

STC 4715 .

In 1569 Cartwright was made Lady Margaret professor at Cambridge and he began his attacks on the established church. These were answered from the pulpit by Whitgift, who, when he became vice-chancellor in 1570, deprived Cartwright of his professorship. He lost his fellowship the following year, and headed for Geneva. One of the Marprelate tracts claims that Cartwright filled a chair of divinity there. 
Cartwright returned to England in 1572, the year Field and Wilcox published their Admonition to the Parliament. This Cartwright supported with his Second admonition to the Parliament. The two brought forth Whitgift's Answer, and the texts above are Cartwright's responses. Hooker, in the prefatory section to his Ecclesiastical polity, remarks of Cartwright:

Concerning the Defender of [the] admonitions, all that I mean to say is but this: there will come a time when three words uttered with charity and meekness shall receive a far more blessed reward than three thousand volumes written with disdainful sharpness of wit.

It is suggested in STC that Froschauer the younger printed the second item in Zürich, though Rudolphi (Froschauer, 1869) does not notice the title. The type face is certainly "strange" in both the Elizabethan sense and the modern; it is a rather squatty Fraktur which stands out beside the items with which the title has been bound. (See illustration, p。17)。

Acc 20588

BILSON, Thomas, 1546?-1616。

The true difference between Christian subjection and unchristian rebellion: wherein the princes lawfull power to commaund for trueth, and indeprivable right to beare the sword are defended against the Popes censures and the Jesuits sophismes uttered in their Apologie and defence of English Catholikes。

At Oxford, Printed by Joseph Barnes, 1585.

Bilson was an Oxford scholar and divine, who became Bishop of Winchester. Anthony à Wood describes him as a principal maintainer of the Church of England. Elizabeth gave Bilson the task of replying to William Allen's Apologie and defence. The queen had food for thought in Bilson's dedicatory remarks: he reminded her that God placed her

in your fathers throne: and expecteth, as it were in recomrence, that the power which he hath given you, and honor which hee hath heaped on you, should bee imployed to protect his trueth, and safegarde his Church within your Realme.

The whole discourse doth so directly and namely treate of your Majesties Scepter, Sirorde, and Crome.o. Let it appeare oo that Princes are placed by God, and so not to bee displaced by men ... o

The Forbes collection also contains his The survey of Christs sufferings (London, Melchisedech Bradiood for John Bill, 1604)。 This titile was his magnum opus, also assigned to him by the queen, Other Bilson titles are already in the Rare Books Department。

Acc 25391

PENRY, John, 1563-1593.

A vieive of some part of such publike wants and disorders as are in the service of God, within her Majesties countrie of Wales o.. Wherein is shewed, not only the necessitie of reforming the state of religion among that people, but also the onely way, in regarde of substaunce, to bring that reformation to passe. 
Plat, The jewell house of art and nature (19337). The 1Ilustrations from Plat's text, with some of his coments.

\section{Upporteblepminge.}

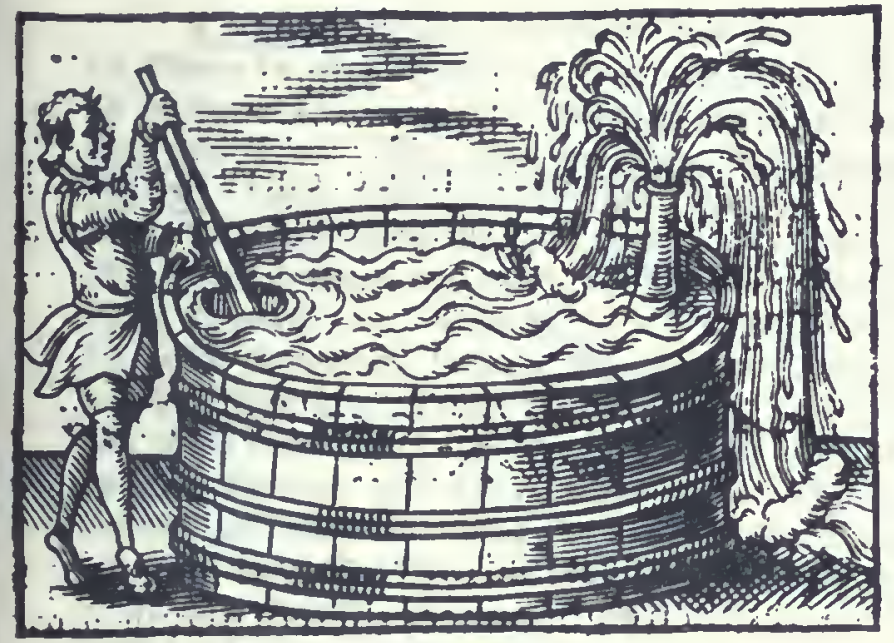

Art and Nature.

21. L round ball of Copper or lation, that rill blow the fire verieftronglie, onely by the attensuation of water into ayre, which deuice will alfo ferme toperfume with.
A viewe of fome part of fuch pub.

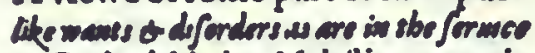
et God, within her Maielties councrio

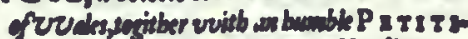
ox,vnwe chishigh Coun of Parlis meat for their geedy redrefte.

G WHEREIN IS SHEVVBD, wot only the nectritic of reforming th these of religien exwons thes people, bue the onely way, in regarde of fubitmines. urieng thereformevion to pette. 
[Coventry, Robert Waldegrave for John Penry, 1589]

Running title: A supplication unto the High Court of Parliament. Page 83 signed: Iohn Penri

STC 19613。

Penry was a Welsh Puritan and thoroughgoing Calvinist. He, John Udall (1560?-1592), Job Throckmorton (1545-1601) and the printer Robert Waldegrave carried out the attack upon the bishops under the pseudonym Martin Marprelate。 Penry is credited with being the chief author of the tracts (although the case is by no means clear-cut) which had to be secretly printed and published, being: in defiance of the law. Penry and Waldegrave had fled to Scotland by 1590 for safety. Though the printer survived to die of natural causes, Penry was arrested on his return to London (1592), tried, drawn on a hurdle and hanged on the charge of inciting rebellion. His Reformation no enemie, published in Scotland, 1590, was used as part of the evidence against him.

A viewe which is sometimes referred to as Penry's Supplication, was printed in Penry's orm type and published in March, 1589. The font matched two unsigned Marprelate tracts, "Martin Junior" i。e., Theses Martinianae and "Martin Senior, i.e., The just censure and reproofe of Martin Junior... by ... Martin Senior, both printed in that year. So secret was the production of $A$ viewe that the printing was done in Coventry, the binding in Northampton, and thence the tracts were carried to London. The clandestine press had been removed from Fawsley in January, 1589 with a stopover for safety's sake at Norton. It left Coventry before May of that year for Wolston Priory, and then was taken to Manchester. Penry's assistant, the binder Henry Sharpe, warned him that the similarity of the type of his own signed works and the Marprelate tracts "would descry him to be Martin". In his deposition before the authorities investigating the secret press, Sharpe stated "The Press wherein they were all printed was Penrys, he was the Dealer with men to print them, he had Books with the first, he could talk of them before they were printed, and of the tymes of their coming forth ...."*

Waldegrave, the printer (1554?-1604), had had his press destroyed for issuing John Udall's anti-Episcopal treatise A demonstration of the truteth of that discipline。o, 1588. He moved with the press as the authorities approached: East Molesy, Fawsley, Coventry, finally Edinburgh. There between 1590-93 he printed controversial tracts, including Penry's; he became King ${ }^{\text {s }}$ Printer in Scotland in 1591. Waldegrave returned to London a year before his death. See illustration of the title page, on page 22. 
Acc 19337

PLAT, Sir Hugh, 1552-1611?

The jewell house of art and nature. Conteining divers rare and profitable inventions, together with sundry new experimentes in the art of husbandry, distillation, and moulding。

London, Peter Short, 1594.

STC 19991。

Three parts, with separate title pages. Illustrated.

The first edition. Sir Hugh Plat (Platt, or Platte) was a student of literature, then science, especially agriculture -- in which he made investigations "of genuine value" (DNB)。Editions of his many interesting works kept on being printed well into the last quarter of the seventeenth century。 He was a tireless experimenter and correspondent on the topics (from manuring to dyeing of the hair) which attracted him. The other parts of The jewell house having separate title pages illustrate his range: "Diverse new sorts of soyle not yet brought into any publique use, for manuring both of pasture and arable ground," and "Divers chimicall conclusions concerning the art of distillation. With many rare practises and uses therof, according to the authors own experience." That his experience need not be questioned seems to be suggested by the note in the Concise DNB: "... son of a London brewer; amply provided for by his father...." It means to suggest that Plat could easily pursue, being well-off, his chemical and agricultural experiments. Some of his other titles include: "The accomplisht ladys delight in preserving, physick and cookery" (Published anonymously, $\mathrm{n}_{\circ} \mathrm{d}_{0}$ ), "Delights for ladies, to adorne their persons, tables, closets and distillatories" (1602, ten editions before 1640), and "Sundrie new and artificiall remedies against famine" (1596)。

MICROFILM ARCHIVES FROM THE VATICAN IN TORCNTO

by

Richard Landon

The Rare Book Room of the University of Toronto Library has recently received on microfilm an important collection of Archives from the Roman Congregation of the Propaganda Fide. They derive from a microfilming project by Professor Emmett Larkin of the University of Chicago, through funds provided by the American Committee for Irish Studies. Copies of the project are deposited in the Irish National Library and St。 Louis University。

The materials chosen are dram principally from the affairs of the Congregation dealing with England, Ireland and Scotland. The Congregatio de Propanganda Fide was formally constituted by Pope Gregory XV in 1622 and charged with responsibility for propagation of the Roman Catholic faith in countries without an established ecclesiastical hierarchy。 The Congregation was administered by a group of cardinals under the direction of a Prefect, meeting monthly at the Congregazione Generale to consider important matters arising from the reports of officers of the areas under Congregational jurisdiction. England, Ireland and Scotland were under this jurisdiction until 1908. 